\title{
COMPANY CHARACTERISTICS AND THE TENDENCY OF FRAUDULENT FINANCIAL REPORTING
}

\author{
Kevin Mulyono Teguh ${ }^{1}$ \\ Ari Budi Kristanto ${ }^{2) *}$ \\ ${ }^{1,2)}$ Fakultas Ekonomika dan Bisnis, Universitas Kristen Satya Wacana \\ Corresponding author: ari.kristanto@uksw.edu
}

Accepted 20 May 2020 / Approved 11 August 2020

\begin{abstract}
Business environment dynamics may influence the companies performance. In those changing situations, the management is expected to satisfy the expectation of its shareholders, even in the worst position. This requires the management to accomplish various decisions, including those related to financial reporting. The management may tend to convey information about their achievement for the investor's expectation through accounting numbers. Financial reporting is important as one of the tools that investors use to see deeper to the company. There are several legal ways to make up the report such as accounting method selection. On the other hand, there are also some illegal ways, such as fraud, and manipulation. This research is aimed to find the relation between company characteristics towards the tendency of fraudulent financial reporting. The research data are taken from the Indonesian Stock Exchange and Compustat from 2014 until 2018. The research uses a logistic regression model for data analysis. The result shows that company size, age, and management integrity have negative relation towards the tendency of fraudulent financial reporting. Contrary to the hypothesis, this research found that audit quality has a positive relation to the tendency of fraudulent financial reporting. This research can contribute to society as additional consideration for the investor.
\end{abstract}

Keywords: Company characteristics, fraudulent financial report.

ABSTRAK : Dinamika lingkungan bisnis dapat mempengaruhi kinerja perusahaan. Dalam situasi yang berubah tersebut, manajemen diharapkan dapat memenuhi harapan pemegang sahamnya, bahkan pada posisi yang paling buruk sekalipun. Hal ini menuntut manajemen untuk mengambil berbagai keputusan, termasuk yang terkait dengan pelaporan keuangan. Manajemen mungkin cenderung menyampaikan informasi tentang pencapaiannya untuk harapan investor melalui laporan keuangan. Pelaporan keuangan penting sebagai salah satu alat yang digunakan investor untuk melihat lebih dalam perusahaan. Ada beberapa cara legal untuk membuat laporan seperti pemilihan metode akuntansi. Di sisi lain, juga terdapat beberapa cara ilegal, seperti penipuan, dan manipulasi laporan keuangan. Penelitian ini bertujuan untuk mengetahui hubungan antara karakteristik perusahaan dengan kecenderungan pelaporan keuangan yang mengandung kecurangan. Data penelitian diambil dari Bursa Efek Indonesia dan Compustat dari tahun 2014 sampai dengan 2018. Analisis datanya menggunakan model regresi logistik. Hasil penelitian menunjukkan bahwa ukuran perusahaan, umur, dan integritas manajemen berhubungan negatif dengan kecenderungan kecurangan pelaporan keuangan. Bertentangan dengan hipotesis, penelitian ini menemukan bahwa kualitas audit berhubungan positif dengan kecenderungan kecurangan pelaporan keuangan. Penelitian ini dapat memberikan kontribusi kepada masyarakat sebagai pertimbangan tambahan bagi investor.

Kata kunci: karakteristik perusahaan, laporan keuangan yang mengandung kecurangan.

\section{Introduction \\ Background}

Businessess are operating in a dynamic rather than a stable condition (Gitman et al., 2018). However, shareholders constrain that their expectation must be fulfilled, regardless of the business condition. There are many reasons why someone wants to invest in a company, but generally the shareholders expectation is to gain return of what they have invested, both in short-term or long-term basis (Chilosi \& Damiani, 2007). When the shareholders expectation aren't met, they may shift their investment, and find another which is more prospective (Darskuviene, 2017). Shareholders are important for the company 
because the company needs the fund from the shareholders to operate their business.

This create an inevitable condition for the management to not only maintain their business operation in the dynamic environment, but also to satisfy the shareholder's expectation. The management may control their internal factors to meet the expectation of the shareholders, but not the external ones (Gitman et al., 2018). One of the important internal factor of the company is the management's decision (Mäenpää, 2016). The higher the pressure from the shareholders and the shareholders' interest, the more attention that the management give towards the issues (Byars \& Stanberry, 2018). This may influence the decision that is taken by the management to fulfill their shareholders' expectation.

Beside the shareholders' expectation, the firm's characteristics is one of the other factors that influence management decision-making process. Elbanna \& Child, (2007) argued that firm's characteristics are more or less influencing the decision-making process of the management. Since there are a lot of possible combination about the firm's characteristics, this gives impact on the decision that the company makes (Papadakis et al., 1998). The difference between these characteristics may influence the management on each company, hence influence their decision.

One of the decision made by the management for the shareholders is about financial reporting. Financial reporting is an important disclosure done by the company, since it's used by the shareholders as an analysis tool to make their decisions (Subair, 2013). By analyzing the financial reports, shareholders will assess whether the company may meet their expectations or not. Thus, the company tends to inform the shareholders about their condition through the financial reports. Seeing the importance of financial reports, the company will find a way to make their financial reports look satisfying and fulfilling the shareholders' expectation.
Companies have several ways to make up their reports, starting from the selection of methods, tax avoidance, manipulation, fraud, etc. While the method selection is allowed by IFRS, manipulation and fraud aren't. The dilemma for the management is when the business condition isn't good, but there are pressures to keep the shareholders' satisfaction. This brings a concern about the tendency of fraudulent financial reporting done by the management to give fake signals to the shareholders that the business is operating well. We have seen a lot of examples about fraudulent financial reporting, such as Enron, WorldCom, Tyco, etc (Ball, 2009). Not only aboard, there are also examples of fraudulent financial reporting such as Garuda Indonesia, SNP Finance, and Jiwasraya.

Previously, Nor et al., (2016) studied the relation between company characteristic and fraudulent financial reporting, based on tax audit evidence result in Malaysia. The research was conducted because there had been a gap among the previous studies, and Nor et al., (2016) wanted to proof that there was a relation between the company characteristic and financial reporting. The result indicated that company size and audit firm size has a significant impact on tax evasion by doing fraudulent financial reporting, while company ownership does not have any significant impacts on the fraudulent financial reporting. Another study by Agustina (2012) focused on the connection between the characteristics of a company with the completeness of financial reports. Chen, et al., (2013) studied the relation between the management integrity and fraudulent financial reporting in China. China and Indonesia have different business culture and condition, so the result of the study in China isn't applicable in Indonesia.

This research applies the model used in the research done by Nor et al., (2016), in Indonesian context. Therefore, it's not relevant to assess the fraudulent financial reporting by using tax audit evidence. In Indonesia. 


\section{Problem Identification}

The previous research by (Nor et al., 2016) use tax audit evidence as one of the measurement for the fraudulent financial reporting. However, tax audit is an independent examination of the data that taxpayers submit (Ebimobowei, 2013). Moreover, the tax audit evidence does not neccesarily show that a company does a fraud in Indonesia. The tax audit result may come from the misinterpretation of taxation regulations, late tax payments, and other violation of tax regulations. It makes the method of the previous study maybe biased if it's applied in Indonesian settings. As a result, a new method that suits the Indonesian environment is needed. Therefore, this research combines the previous research by using another method, named F-Score.

\section{Research Purpose}

The research purpose of this study is to find out the relation between the company characteristics and the tendency of doing fraudulent financial reporting. It brings to the research question 'what are the company characteristics that show the tendency of commiting fraudulent financial reporting'.

This research is expected to give several benefits for the society. For the shareholders, this research is expected to give additional considerations before investing in a certain company. For researchers, this study is expected to be one of the base or resource for further study, and for the tax officials, this study is expected to show the indicators of companies which some extra attention needs to be put at

\section{Hypothesis Development}

Company characteristics can be defined as the unique characteristics that belong to a company (Badriyah et al., 2015). Company characteristics may vary from profitability ratio, leverage ratio, firm age, audit comitee, audit quality, etc. When these various characteristics are combined, it will give a company an unique identity. This identity will not be the same among companies, even if they are subsidiaries of a certain company. Previous studies found that the differences in characteristics lead to a different companies decision (Ahmed \& Muhammed, 2018; Gomez-mejia et al., 2010).

In this research, the firm characteristics used are the firm size, firm age, managerial integrity, and audit quality. It's common to measure a company from several aspects, such as performance, ownership structure, governance, and industry type (Mapitiya, 2017). The choice of the four characteristics mentioned above is expected to see a company from various aspects, not only from a single aspect.

Fraudulent financial reporting is defined as the fraud that happens in terms of financial reports (Mp \& Irwandi, 2016). The fraudulent financial reporting may happen because a company wants to show a satisfactory financial reports to the shareholders, in order to fulfill their expectations (Apriliana \& Agustina, 2017). The fraudulent financial reporting has a negative impact towards the shareholders, in which they receive a false information about the company they want to invest in. This may lead to the wrong investment done by the shareholders and may lead to the shareholders' loss. Fraudulent financial reporting also has a negative impact on the company. Fraudulent financial reporting can be done through various ways, but the most common forms are overstatement of assets or revenue, and understatement of liabilty and expense (Dalnial et al., 2014).

Firm size is one of the common firm characteristics used to measure a company's financial reports. There are several different ways to measure firm size, such as through the total asset (Niresh \& Velnampy, 2014). Another indicator to measure firm size is the total sales (Nor et al., 2016).

According to the political cost hypothesis, the larger the firm size, the higher it's political cost (Athanasios et al., 2013). Moreover, Zimmerman (1983) stated that political cost has a direct relationship towards the firm size, because the bigger the 
firm, the more visible the firm is. The bigger the company will also make it the closer object of attention from people and government (Wuryani, 2012). Moreover, Embong et al., (2012) stated that bigger firms will disclose more information in order to maintain their reputation.

Bigger companies have a better internal control compared to the smaller ones (Wuryani, 2012). Rezaei \& Shabani, (2015) strengthened the statement by arguing that larger firms will have more procedures, organizational methods and also accurate guidelines to control the firms. Because of better internal control, doing fraud is difficult. Better internal control results to the accuracy of the financial statement disclosed. Thus, it leads to the first hypothesis:

$H_{1}$ : Firm size has a negative relation with the tendency of Fraudulent Financial Reporting

Firm age is one type of company characteristic that can be used to measure the company financial reports. It is defined as the length of time during which the company has existed or incorporated (Ilaboya \& Ohiokha, 2016). The older the company, the more experience it has. Hence, it has improved the expertise compared to the younger firms (Waluyo, 2017). As a result, an older company tends to have an improved efficiency. Older company also tends to have more investors compared to the younger ones (Guha, 2017). Companies will try to meet the demand of their investors, and inform them by using financial reports that is disclosed to the investors. (Lucyanda \& Siagian, 2012)

The firm age is also connected with the firm's internal control. Olowokure et al., (2016) argued that by the time passes the company will experience several problems, thus improving their corporate governance. One way to improve corporate governance is by improving their internal control. The stronger the internal control of a company, the more reliable that their financial report is (Huang et al., 2012). Therefore this leads to the second hypothesis:
$\mathrm{H}_{2}$ : Firm age has a negative relation with the tendency of fraudulent financial reporting

Integrity is defined as keeping commitment on time, or acknowledge when failing to fulfill and try to fix that (Dikolli, Mayew, \& Steffen, 2013). Hanim \& Bakri, (2017) define integrity as the degree of people satisfying the expectation of the world around them. In the case of management, integrity is needed, especially for the decision-maker level management. It's because every decision will be influencing all other decisions related with the company (Nowak \& Mccabe, 2003). Integrity is also needed by the management to reach a value maximization, which means to bring the best result they can give to the company (Chen et al., 2013)

Problems occur when the manager believes that the reputational cost is lower than the potential gains the manager will receive, they tend to violate their integrity as a manager (Bradford, 2006). The example is the budget-bonus system encourages poor integrity since the system gives rewards for lying, but punish someone for telling the truth (Chen et al., 2013). The most common action done by managers is to increase their bonus by doing earning management. Dikolli, Mayew, \& Steffen, (2013) argued that there are an empirical evidence between managerial integrity and earnings management. The more integrity a manager has, the more reliable the decisions that they made. Therefore, it leads to the third hypothesis:

\section{$H_{3}:$ Management integrity has a negative relation with fraudulent financial reporting}

An auditor plays a big role to ensure the reliability of the financial reports that are disclosed to the public. Audit quality is defined as the probability of the auditor to find and report the fraud happended in the client's report (Deis \& Giroux, 2013). The study conducted by Parte-esteban \& Ferrer, (2014) suggested that by using bigger audit firm such as Big 4 audit firms, will give better assurance compared to using the smaller ones. It's because when bigger audit 
companies give a low quality audit reports, they will lose their reputation and trust, so they will likely give better audit quality reports. The higher audit quality reports are expected to have more accurate data, as well as to reduce the fraudulent financial reporting (Nor et al., 2016). This leads to the last hypothesis:

$H_{4}$ : Audit firm size has a negative relation towards the tendency of fraudulent financial reporting

\section{Research Method \\ Data}

This is a quantitative research with the purpose to find out whether the company factors (firm size, firm age, managerial integrity, and audit quality) have impacts on the tendency of fradudulent financial reporting (TFFR) among the companies in Indonesia. The data used in this research is secondary data such as total asset, total liabilities, total sales, total inventory, total receiveables, cashflow from operation, and profit of the year. The data source is the financial statements and annual reports of the Indonesian companies listed and published in the Indonesian Stock Exchange on www.idx.co.id.

\section{Population and Sampling}

The population of this research are all of the Indonesian companies registered in the Indonesian Stock Exchange and recorded in Compustat consecutively from 2014 to 2018. For the sample selection, the purposive sampling technique is used. The first criteria for the samples is that they have been registered in Indonesian Stock Exchange and Compustat consecutively from 2014 to 2018. The second criteria is they have sufficient the data needed for this research.

\section{Research Variable}

The independent variables used in this research are firm size, firm age, managerial integrity, and audit quality. The firm size is the measurement of how big or small a company is, measured by the natural logarithm of total sales of the company (Athanasios et al., 2013; Nor et al., 2016;
Wuryani, 2012). The firm age is the duration of how long the company has been operating. This variable is measured by how many years the company has been operating since it was founded (Harvie, Narjoko, \& Oum, 2010; Waluyo, 2017).

The management integrity is proxied by earnings management, which is calculated using Modified Jones Discretionary Accrual. As suggested by Darmawati, (2003) and Suyono, (2017), Modified Jones Discretionary Accrual is the best method to measure earning management. The result of the discretionary accrual will be transformed into absolute numbers. The steps to calculate Modified Jones Discretionary Accrual are as follows:

I. Counting the total accrual (TAC) $\mathrm{TAC}=\mathrm{NI}_{\mathrm{it}}-\mathrm{CFO}_{\mathrm{it}}$

II. Estimating TAC with OLS regression to get the regression coefficient $\left(\mathrm{TA}_{\mathrm{it}} / \mathrm{A}_{\mathrm{it}-1}\right)=\beta_{1}\left(1 / \mathrm{A}_{\mathrm{it}-1}\right)+\beta_{2}\left(\Delta \operatorname{Rev}_{\mathrm{it}} / \mathrm{A}_{\mathrm{it}-}\right.$ $\left.{ }_{1}\right)+\beta_{3}\left(\Delta \operatorname{Rec}_{\mathrm{it}} / \mathrm{A}_{\mathrm{it}-1}\right)+\varepsilon$

III.Calculating the Non-Discretionary Accrual

$\mathrm{NDA}_{\mathrm{it}}=\beta_{1}\left(1 / \mathrm{A}_{\mathrm{it}-1}\right)+\beta_{2}\left(\Delta \operatorname{Rev}_{\mathrm{it}} / \mathrm{A}_{\mathrm{it}-1}-\right.$ $\left.\Delta \operatorname{Rec}_{\mathrm{it}} / \mathrm{A}_{\mathrm{it}-1}\right)+\beta_{3}\left(\Delta P \mathrm{PE}_{\mathrm{it}} / \mathrm{A}_{\mathrm{it}-1}\right)+\varepsilon$

IV. Calculating the Discretionary Accrual

$\mathrm{DA}_{\mathrm{it}}=\left(\mathrm{TAC}_{\mathrm{it}} / \mathrm{A}_{\mathrm{it}-1}\right)-\mathrm{NDA}_{\mathrm{it}}$

Where:

$\mathrm{DA}_{\mathrm{it}}=$ Discretionary Accrual at year $\mathrm{t}$

$\mathrm{NDA}_{\text {it }}=$ Non Discretionary Accrual at year

$\mathrm{t}$

$\mathrm{TA}_{\text {it }}=$ Total Accrual at year $\mathrm{t}$

$\mathrm{NI}_{\mathrm{it}} \quad=$ Net Income at year $\mathrm{t}$

$\mathrm{CFO}_{\text {it }}=$ Cash Flow From Operation at year $\mathrm{t}$

$\mathrm{A}_{\mathrm{it}-\mathrm{1}}=$ Total Asset at year $\mathrm{t}-1$

$\Delta \operatorname{Rev}_{\text {it }}=$ Revenue at year $\mathrm{t}-$ Revenue at $\mathrm{t}-1$

$\Delta \operatorname{Rec}_{\text {it }}=$ Receiveable at year $\mathrm{t}-$

Receiveable at $\mathrm{t}-1$

$\mathrm{PPE}_{\mathrm{it}}=$ Fixed Asset atyear $\mathrm{t}$

$\varepsilon \quad=$ Error

Audit firm size is also divided into 2 categories, which is big audit firm and small-medium audit firm (Khairunisa \& Yustrianthe, 2015; Lestari \& Murtanto, 2017; Nor et al., 2016). Big audit firms consist of the Big 4 audit firms in Indonesia 
such as Ernst and Young, Deloitte, KPMG, and PricewaterhouseCooper. Small-medium audit firm size points out the other audit firms that are not mentioned above. The companies that use the service of a Big 4 audit companies will be coded as 1 , and those that do not are given 0 as their code.

The dependent variable of this research is the tendency of fraudulent financial reporting, which is measured using F-Score model. F-Score model is a model to determine the likelihood of discovering and predicting material misstatement in the financial report developed by (Dechow et al., 2010). The F-Score has been used in the previous research (Annisya, Lindrianasari, \& Asmaranti, 2016; Hung \& Binh, 2017; Skousen \& Twedt, 2009). This method measures the probability of a fraud using financial statement data, which are accrual quality and firm performance. The value of F-Score can be measured by adding the value of accrual quality and financial performance (Skousen \& Twedt, 2009)

Fscore $=$ Accrual Quality + Financial Performance

Accrual quality can be measured using RSST accrual (Annisya et al., 2016; Hung \& Binh, 2017). The RSST accrual is measured by summing up the working capital, non current operating accrual, and financial accrual, then dividing it with the average total asset. Financial performance is the sum up value of its elements, which are changes in receiveables, inventories, cash sales, and earning. The output of the FScore analysis is an index that indicates the tendency of fraudulent financial reporting. If the value of F-Score is above 1.00, it indicates that there is the tendency of fraud happening in that certain company. Code 1 will be given for the company that has FScore value for more than 1 , and code 0 will be given for the company that has F-Score lower than 1 .

$\mathrm{RSST}$ Accrual $=(\Delta \mathrm{WC}+\Delta \mathrm{NCO}+\Delta \mathrm{FIN}) /$ ATA

$\mathrm{FP}=$ Change in receiveable + change in inventories + change in cash sales + change in earning
Change in receiveable $=\Delta$ Receiveable $/$ ATA

Change in inventories $=\Delta$ Inventories/ATA

Change in cash sales $=\left(\Delta\right.$ Sales $/$ Sales $\left._{n}\right)-$ $\left(\Delta\right.$ receiveables/Receiveables $\left._{n}\right)$

Changes in earning $=\left(\right.$ Earnings $_{\mathrm{n}} /$ ATA $)-$ $\left(\right.$ Earnings $_{n-1} /$ ATA $\left._{n-1}\right)$

Where

WC $($ Working Capital $)=$ Current Asset Current Liability

$\mathrm{NCO}$ (Non Current Operating Accrual $)=$

(Total Asset - Current Asset - Investment and Advances) - (total Liabilities - Current Liabilities - Long Term Debt)

FIN $($ Financial Accrual $)=($ Short $\quad$ Term Investment + Long Term Investment) (Long Term Debt + Debt Within ShortTerm Debt + Preferred Shares)

ATA $($ Average Total Asset $)=($ Beginning Total Assets + End Total Assets)/2

\section{Research Model}

This research is intended to find the tendency of fraud by using several variables such as firm size, firm age, firm type and audit quality. So the data analysis method used is the logistic regression. The model of this research is:

TFFR $=\beta 0+\beta$ SZE $+\beta$ AGE $+\beta$ MGMT + $\beta$ AUDIT $+\varepsilon$

Where:

TFFR = Tendency of fraudulent finanancial reporting

SZE = Company size

AGE = Company age

MGMT = Management Integrity

AUDIT = Audit Firm

Result and Analysis

Table 1. Sample Criteria

\begin{tabular}{llrl}
\hline No & Information & Total \\
\hline 1 & Company listed in IDX & 601 \\
& and Compustat from 2014 &
\end{tabular}




\begin{tabular}{|c|c|c|}
\hline & to 2018 & \\
\hline 2 & $\begin{array}{l}\text { Company doesn't have } \\
\text { complete data }\end{array}$ & $(254)$ \\
\hline \multirow[t]{6}{*}{3} & $\begin{array}{l}\text { Company with extreme } \\
\text { data }\end{array}$ & $(20)$ \\
\hline & Total Sample & 327 \\
\hline & Period & 4 \\
\hline & Observed data & 1308 \\
\hline & Outlier in SPSS & (2) \\
\hline & Total Observation & 1306 \\
\hline
\end{tabular}

There are 601 companies listed in Indonesian Stock Exchange and Compustat from 2014 to 2018. 254 companies among them are eliminated due to the incomplete data that will be used in this research. 20 other companies are also eliminated from the sample because of the extreme data they had. This left 327 companies that meet the requierement. With 4 years of observation, there are 1308 data that is observed. After processing the data with SPSS, there are 2 outliers detected and removed. In the end, there are 1306 data that is valid for the research.

\section{Descriptive Statistic}

Table 2. Descriptive Statistic

\begin{tabular}{lccc}
\hline & Minimum & Maximum & Mean \\
\hline FSCORE & 0 & 1 & 0,11 \\
SIZE & 21 & 33 & 28,14 \\
AGE & 0,32 & 0,70 & 0,55 \\
\hline
\end{tabular}

\begin{tabular}{llcc}
\hline MGMT & 0 & 24,14 & 0,14 \\
AUDIT & 0 & 1 & 0,41 \\
\hline
\end{tabular}

Source : Processed data using SPSS 25

Based on the table above, FSCORE on the observation has a minimum value of 0 and maximum value of 1 , while having mean value of 0,11 . There are $88,62 \%$ samples that have the value below the mean, which means that these companies have lower tendency of doing fraudulent financial statement. SIZE variable has a minimum and maximum value of 21 and 33, and mean value of 28,14. From 1306 samples, there are $42,27 \%$ samples that have the value above the median, which indicate that these companies are bigger companies. AGE variable on the observation have a minimum value of 0,32 and maximum value of 0,70 . There are $59,57 \%$ observation that has the value above mean of 0,55 , which means that these companies are older companies.

The MGMT variable on the observation has a minimum value of 0 and the maximum of 24,14 . There are $24,73 \%$ observations whose value is above the mean of 0,14 . The companies that have a bigger value than the mean depicts that they have a greater earning management. AUDIT variable on the observation has a minimum value of 0 and the maximum value of 1 . The mean is 0,41, and there are 59,04\% observations which are below the mean. The observation that is below the mean indicates that they are having a non-big 4 auditor as their auditor.

\section{Goodness of Fit Test, Model Fit Test, and Model Clarification Power}

Table 3. List of Test Summary

\begin{tabular}{|c|c|c|c|}
\hline Test & Method & Result & Conclusion \\
\hline $\begin{array}{l}\text { Goodness of } \\
\text { Fit }\end{array}$ & $\begin{array}{l}\text { Hosmer } \\
\text { Lemeshow }\end{array}$ & Significancy of 0,793 & Pass The Test \\
\hline $\begin{array}{l}\text { Model Fit } \\
\text { Testing }\end{array}$ & -2Log Likelihood & $\begin{array}{l}-2 \text { Log Likelihood } \\
\text { decreasing by } 49,308\end{array}$ & $\begin{array}{l}\text { The addition of independent } \\
\text { variable makes the model } \\
\text { become better }\end{array}$ \\
\hline $\begin{array}{l}\text { Model Fit } \\
\text { Testing }\end{array}$ & Omnibus Test & Significancy of 0,000 & $\begin{array}{l}\text { Independent variable has a } \\
\text { simultant effect on dependant } \\
\text { variable }\end{array}$ \\
\hline $\begin{array}{l}\text { Model } \\
\text { Clarification } \\
\text { Power }\end{array}$ & $\begin{array}{l}\text { Classification } \\
\text { Table }\end{array}$ & $\begin{array}{l}\text { Predicted Correct } \\
\text { Percentage of } 88,7 \%\end{array}$ & $\begin{array}{l}\text { The regression model can } \\
\text { correctly predict the condition } \\
\text { by } 88,7 \%\end{array}$ \\
\hline
\end{tabular}


Source : Processed data using SPSS 25

Hosmer and Lemeshow's Goodness of Fit Test is a test to provide an evidence that the empirical data fits with the model, or there are no difference between the data and the model. The significancy level of this test is 0,05 . If the significancy result is more than 0,05 , it means that the model is accepted. From this research, the statistical result is 4,662 with significancy of 0,793 , which is above 0,05 . So it's concluded that the model is accepted.

From the table above, the result of Log Likelihood is decreasing, from step 0 amounted to 914,840 to step 1 with the amount of 865,532 . The decrease value is
49,308. This reduction means that after several variables (size, age, management integrity, and audit quality), the regression model becomes better. Table 2 above also shows that the significance level is 0,000 , which is lower than 0,05 . It means that the independent variables used in the research simultaneously affect the dependant variable.

The clasisification table above shows the predictive value from the dependent variables. The result from the test is that this logistic regression model can correctly predict $88,7 \%$ condition that happend.

\section{Hypothesis Testing} below

The tests for hypothesis $1,2,3$ and 4 are based on the results of the logistic regression

Tabel 4. Hypothesis Testing Result

\begin{tabular}{lll}
\hline & B & Sig \\
\hline SIZE & $-0,279$ & 0,000 \\
AGE & $-2,949$ & 0,042 \\
MGMT & 0,747 & 0,014 \\
AUDIT & 0,423 & 0,037 \\
\hline \multicolumn{2}{l}{ Nagelkerke R Square } & 0,074 \\
\hline \multicolumn{2}{l}{ Source : Processed data using SPSS 25 } \\
\hline
\end{tabular}

The table above explains that the result of Nagelkerke $\mathrm{R}$ Square is 0,074 . It means that there are $7,4 \%$ contribution to predict the tendency of fraudulent financial reporting from the observed variables. The other $92,6 \%$ is explained by other factors outside the observed variables.

Firm size variable (SIZE) shows a negative regression coefficient amounted by ,- 279 , with the significance value of 0,000 . This indicates that there is a significant negative influence of firm size towards the tendency of fraudulent financial reporting

Firm age variable (AGE) has a reggression coefficient of $-2,949$. It shows that there is a negative relationship between firm age and the tendency of fraudulent financial reporting. With the significance level of 0,042 , which is below 0,05 , the AGE variable has a significant effect on the dependent variable.
Management Integrity (MGMT) which is proxied by earnings management has the regression coefficient of 0,747 and the significance value of 0,014 . It means that earning management has a positive significant effect towards the tendency of fraudulent financial reporting. Since higher earning management level shows that the management's integrity is low, it means that management integrity has a negative significant relation with the tendency of fraudulent financial reporting.

The audit quality has a rgression coefficient of 0,423 , while having the significance level of 0,037 . This indicates that audit quality which is proxieed by the size of audit firm has a positive significant influence towards the tendency of fraudulent financial reporting. 


\section{Discussion}

\section{Firm Size and Fraudulent Financial Reporting.}

The result of this research shows that bigger companies are having less tendency to fraudulent financial reporting. Therefore, the first hypothesis is supported. In relation with the political cost theory, bigger firms have a higher level of political cost. It means that bigger companies will have higher reputation compared to the smaller ones. Therefore, bigger companies will dislose better information to maintain their reputation. Also, bigger companies will have better internal control. The level of internal control will affect the accuracy of their financial statement, because a strict internal control makes it harder to do fraud.

The result of this research is in line with the previous research by (Nor et al., 2016). They found a significant negative relation between firm size and the tendency of fraudulent financial report, which is measured by total sales. Wuryani, (2012) also found a negative significant relation between firm size and fraud.

\section{Firm Age and Fraudulent Financial Reporting.}

This research found that older companies will have a lesser tendency to do a fraudulent financial reporting. Thus, the second hypothesis is also supported. Older companies will have more expertise compared to the younger ones, since they have gone through many problems and are still operating. This creates expertise which will increase their efficiency as a company, as well as a better internal control. With a better internal control, the tendency of doing fraudulent financial reporting can be constrained.

The result of this research is in line with by the research done by Ewelt-Knauer, Thorsten, \& Lachmann, (2015), which also found that there is a negative significant relationship between firm age and fraudulent financial reporting. Olowokure et al., (2016) found that the older the company, the more experience as well as better corporate governance they have. Thus the tendency of fraud is reduced. Older companies also tend to have better internal control (Waluyo, 2017). Better internal control means that their financial reports are more reliable and free from error.

\section{Management Integrity and Fraudulent Financial Reporting}

The result of this research found that the the more the management does the earning management, the more tendency of doing fraudulent financial reporting. Therefore, the third hypothesis is supported. Management decisions will eventually affect other decisions made by the company. The higher integrity that a management has, the higher the value maximization, which will eventually the best result to the company itself. When the management lost their integrity, they will tend to maximize their own interest, while sacrificing the company's interest. This will lead to a disadvantage for the company in the long run.

This research is in line with the previous research done by Bakri et al., (2017) who found that management integrity has a significant negative relation with the fraud. Chen et al., (2013) also found similar results in their research about management integrity and fraud. This shows that the lower the management integrity is, the more exposed the company to fraud. Moreover, lower managemet integrity leads to a higher fraud risk (Irianto et al., 2009)

\section{Audit Quality and Fraudulent Financial Reporting}

The result of this research showed that companies with higher audit quality have bigger tendency of committing fraudulent financial reporting. Threfore, the hypothesis is not supported. The high level of audit quality will make the accounting flexibility of a company being reduced. Since the accounting flexibility is shrinking, apparently the company will find other ways to do fraud. This statement strengthen the previous research done by Boedhi \& Ratnaningsih (2015) and Aryanti, Kristanti, \& Hendrayatno (2017) who found a significant positive relation between audit quality and real earning management. Real earning management becomes a choice 
because it's much harder to be found by the auditor (Ningsih, 2015). Those research give empirical evidences that Big 4 auditors are unable to completely constrain financial misstatements commited by the company. There are several cases where companies being audited by the Big 4 auditors are condemned guilty by the Financial Service Authority of Indonesia (OJK). Some of them are Deloitte in 2018 for SNP Finance cases, Ernst \& Young in 2019 for Hanson cases, and PricewaterhouseCoopers for Jiwasraya cases in 2019, although there are not yet any sactions applied for PricewaterhouseCooper.This result is not in line with the previous research by (Nor et al., 2016) and (Parte-esteban \& Ferrer, 2014). Both of those previous research have the result of negative significant for audit quality, measured by size of auditor towards the tendency of fraud. In other hand, this research result matches the result of the research by Boedhi \& Ratnaningsih (2015) and Aryanti, Kristanti, \& Hendrayatno (2017).

\section{Conclusion}

The result of this research showed that size, age, and management integrity have a significant negative relation with the tendency of fraudulent financial reporting. Meanwhile, this research found that audit quality has a positive significant relation towards the tendency of fraudulent financial reporting. This is in contrary with the general mindset of people where higher audit quality will generate lower tendency of fraudulent financial reporting. This may happen because the company that hires the Big 4 auditors only does this to attract investors, or there might be low integrity person in the company, or in the auditor firms.

There are several implication of this research. The theoritical implication of this research is that the results are in line with those done by Boedhi \& Ratnaningsih, (2015), Chen et al., (2013), Ewelt-Knauer et al., (2015),
Waluyo, (2017), and Wuryani, (2012) . on the other hand, the results of this research are on the contrary to the research done by (Nor et al., 2016) and Parte-esteban \& Ferrer, (2014). The applied implication of this research for the society is that this research can contribute an additional consideration before investing. Therefore, by considering the age, size, and the integrity of a company, the investor can choose the one that has less tendency of fraudulent financial reporting. For the researcher, this research is expected to give deeper explanation and can be expanded into a broader range of study, which are expected to cover broader, and more complex business characteristics. Lastly, for the officials, this study can be an alternate ways to detect companies that have a tendency of doing fraudulent financial reporting. This research are not free from weakness and limitation. The weakness of this research is that the model used in this research is still simple. It's possible for the future researchers to expand the research model by adding more variables, or testing the mediation or moderation effect of certain variables such as the moderating effect of audit fee or industrial specialization auditor towards the tendency of fraudulent financial report, so that the research model will be better. 
Reference

Agustina, L. (2012). Pengaruh Karakteristik Perusahaan Terhadap Pengungkapan Laporan Tahunan. Jurnal Dinamika Akuntansi, 4(1), 55-63.

Ahmed, A. M., \& Muhammed, A. A. (2018). Internal Control Systems \& Its Relationships With The Financial Performance In Telecommunication Companies - A Case Study Of Asiacell \|. International Journal of Cientific \& Technology Research, 7(11), 82-88.

Annisya, M., Lindrianasari, L., \& Asmaranti, Y. (2016). Pendeteksian Kecurangan Laporan Keuangan Menggunakan Fraud Diamond. Jurnal Bisnis Dan Ekonomi, 23(1), 72-89.

Apriliana, S., \& Agustina, L. (2017). The Analysis of Fraudulent Financial Reporting Determinant through Fraud Pentagon Approach. Jurnal Dinamika Akuntansi, 9(2), 154-165.

Aryanti, I., Kristanti, F. T., \& Hendrayatno. (2017). Kepemilikan institusional, kepemilikan manajerial, dan kualitas audit terhadap manajemen laba. Jurnal Riset Akuntanti Kontemporer (JRAK), 9(2), 66-70.

Athanasios, V., Antonios, S., \& Despina, G. (2013). Company Characteristics and Human Resource Disclosure in Greece. Procedia Technology, 8(Haicta), 112-121. https://doi.org/10.1016/j.protcy.2013.1 1.016

Badriyah, N., Sari, R. N., \& Basri, Y. M. (2015). The effect of corporate governance and firm characteristics on firm performance and risk management as an intervening variable. Procedia Economics and Finance, 31(15), 868-875. https://doi.org/10.1016/S22125671(15)01184-3

Bakri, H. H. M., Mohamed, N., \& Said, J. (2017). Mitigating asset misappropriation through integrity and fraud risk elements. Journal of Financial Crime, 24(2), 242-255. https://doi.org/10.1108/JFC-04-20160024

Ball, R. (2009). Market and Political /
Regulatory Perspectives on the Recent Accounting Scandals. Journal of Accounting Research, 47(2), 277-323. https://doi.org/10.1111/j.1475679X.2009.00325.X

Boedhi, N. R., \& Ratnaningsih, D. (2015). PENGARUH KUALITAS AUDIT TERHADAP MANAJEMEN LABA MELALUI AKTIVITAS RIIL. KINERJA, 19(1), 84-98.

Bradford, B. (2006). Because that's where the money is: toward a theory and strategy of corporate legal compliance (Vol. 419).

Byars, S. M., \& Stanberry, K. (2018). Business Ethics. Rice University.

Chen, J., Cumming, D., Hou, W., \& Lee, E. (2013). Executive integrity , audit opinion , and fraud in Chinese listed firms. Emerging Markets Review, 15, 72-91.

https://doi.org/10.1016/j.ememar.2012. 12.003

Chilosi, A., \& Damiani, M. (2007). Stakeholders vs. Shareholders in Corporate Governance. Munich Personal RePEc Archive, (2334).

Dalnial, H., Kamaluddin, A., Sanusi, Z. M., \& Khairuddin, K. S. (2014). Detecting Fraudulent Financial Reporting through Financial Statement Analysis. Journal of Advanced Management Science, 2(March 2014), 16-22. https://doi.org/10.12720/joams.2.1.1722

Darmawati, D. (2003). CORPORATE GOVERNANCE DAN MANAJEMEN LABA: SUATU STUDI EMPIRIS. Jurnal Bisnis Dan Akuntansi, 5(1), 47-68.

Darskuviene, V. (2017). Stakeholder Expectations and Influence on Company Decisions, (August). https://doi.org/10.7220/AESR.2335.87 42.2014.8.2.5

Dechow, P. M., Hall, M., Larson, C. R., \& Sloan, R. G. (2010). Predicting Material Accounting Misstatements. Contemporary Accounting Research

Deis, D. R., \& Giroux, G. A. (2013). Determinants of in Audit Sector Quality the Public. The Accounting Review, 67(3), 462-479. 
Dikolli, S. S., Mayew, W. J., \& Steffen, T. D. (2013). Honoring One's Word: CEO Integrity and Accruals Quality.

Ebimobowei, A. (2013). A Causality Analysis between Tax Audit and Tax Compliance in Nigeria. European Journal of Business and Management, 5(2), 107-121.

Elbanna, S., \& Child, J. (2007). The Influence of Decision, Environmental and Firm Characteristics on the Rationality of Strategic DecisionMaking * Said Elbanna and John Child. Journal of Management Studies, 44(June 2007), 562-591. https://doi.org/10.1111/j.14676486.2006.00670.x

Embong, Z., Mohd-saleh, N., \& Hassan, M. S. (2012). Firm size, disclosure and cost of equity capital. Asian Review of Accounting, 20(2), 119-139. https://doi.org/10.1108/132173412112 42178

Ewelt-Knauer, C., Thorsten, K., \& Lachmann, M. (2015). Fraud characteristics and their effects on shareholder wealth. Journal of Business Economics. https://doi.org/10.1007/s11573-0150773-5

Gitman, L. J., McDaniel, C., Shah, A., Reece, M., Koffel, L., Talsma, B., \& Hyatt, J. C. (2018). Introduction to Business. Rice University.

Gomez-mejia, L. R., Makri, M., \& Kintana, M. L. (2010). Diversification Decisions in Family-Controlled Firms. Journal of Management Studies, 252(March), 223-252. https://doi.org/10.1111/j.14676486.2009.00889.x

Guha, S. (2017). Institutional Investors and firm characteristics: new evidence from India. Research in International Business and Finance. https://doi.org/10.1016/j.ribaf.2017.09. 005

Harvie, C., Narjoko, D., \& Oum, S. (2010). Firm Characteristic Determinants of SME Participation in Production Networks, (8).

Huang, H., Rose-green, E., \& Lee, C. (2012). CEO Age and Financial
Reporting Quality. Accounting Horizons, 26(4), 725-740. https://doi.org/10.2308/acch-50268

Hung, D. N., \& Binh, D. T. (2017). Application of F-Score in Predicting Fraud, Errors : Experimental Research in Vietnam. International Journal of Accounting and Financial Reporting, 7(2), 303-322. https://doi.org/10.5296/ijafr.v7i2.1217 4

Ilaboya, O. J., \& Ohiokha, I. F. (2016). Firm Age, Size and Profitability Dynamics : A Test of Learning by Doing and Structural Inertia Hypotheses. Buseiness and Management Research, 5(1), 29-39. https://doi.org/10.5430/bmr.v5n1p29

Irianto, G., Novianti, N., Rosalina, K., \& Firmanto, Y. (2009). INTEGRITY , UNETHICAL BEHAVIOR , AND TENDENCY OF FRAUD. Jurnal Ekonomi Dan Keuangan, (110).

Khairunisa, A. A., \& Yustrianthe, R. H. (2015). Kajian Empiris Faktor-Faktor Yang Mempengaruhi Kualitas Audit. Jurnal Ilmiah Wahana Akuntansi, 10(1), 1-23.

Lestari, E., \& Murtanto, M. (2017). PENGARUH EFEKTIVITAS

DEWAN KOMISARIS DAN KOMITE AUDIT , STRUKTUR KEPEMILIKAN , KUALITAS AUDIT. Jurnal Media Riset Akuntansi, Auditing \& Informasi, 17(2), 97-116.

Lucyanda, J., \& Siagian, L. G. P. (2012). The Influence of Company Characteristics Toward Corporate Social Responsibility Disclosure. The 2012 International Conference on Business and Management, 601-619.

Mäenpää, M. (2016). The Importance of Shareholder Value in DecisionMaking.

Mapitiya, G. (2017). Ownership Types , Corporate Governance and Corporate Performance: The Mediating Effect of Corporate Governance Practices Ownership Types , Corporate Governance and Corporate Performance: The Mediating Effect of Corporate Governance Practices. Sri 
Lankan Journal of Management, 20(January-June), 30-57.

Mp, N. P., \& Irwandi, S. A. (2016). The effect of firm size, financial performance, listing age and audit quality on Internet Financial Reporting. The Indonesian Accounting Review, 6(2), 239-247. https://doi.org/10.14414/tiar.v6i2.614

Ningsih, S. (2015). EARNING MANAGEMENT MELALUI AKTIVITAS RIIL DAN AKRUAL. Jurnal Akuntansi Dan Pajak, 16(1), 55-66.

Niresh, J. A., \& Velnampy, T. (2014). Firm Size and Profitability: A Study of Listed Manufacturing Firms in Sri Lanka. International Journal of Business and Management, 9(4), 5764.

https://doi.org/10.5539/ijbm.v9n4p57

Nor, J. M., Ahmad, N., \& Saleh, N. M. (2016). Fraudulent financial reporting and company characteristics : tax audit evidence. Journal of Financial Reporting and Accounting, 8(2), 128142.

https://doi.org/10.1108/198525110110 88389

Nowak, M. J., \& Mccabe, M. (2003). Information Costs and the Role of the Independent Corporate Director. Corporate Governance: An International Review, 11(4), 300-307.

Olowokure, O. A., Tanko, M., \& Nyor, T. (2016). Firm Structural Characteristics and Financial Reporting Quality of Listed Deposit Money Banks in Nigeria. International Business Research, 9(1), 106-122. https://doi.org/10.5539/ibr.v9n1p106

Papadakis, V. M., Lioukas, S., \& Chambers, D. (1998). STRATEGIC DECISIONMAKING PROCESSES : THE ROLE OF MANAGEMENT AND CONTEXT. Strategic Management Journal, 19(July 1995), 115-147.

Parte-esteban, L., \& Ferrer, C. (2014). The influence of firm characteristics on earnings quality. International Journal of Hospitality Management, 42, 50-60. https://doi.org/10.1016/j.ijhm.2014.06. 008
Rezaei, F., \& Shabani, A. (2015). A study of the effect of firm size and quality of disclosure on the cost of company common stock. Intetnational Journal of Innovation and Applied Studies, 10(3), 1038-1045.

Skousen, C. J., \& Twedt, B. J. (2009). Fraud score analysis in emerging markets. Cross Cultural Management: An International Journal, 16(3), 301-316. https://doi.org/10.1108/135276009109 77373

Subair, F. (2013). Karakteristik Perusahaan Dan Industri Terhadap Pengungkapan Dalam Laporan Keuangan Pada Perusahaan Manufaktur Yang Go Publik. Jurnal EMBA, 1(3), 763-774.

Suyono, E. (2017). BEBAGAI MODEL PENGUKURAN EARNINGS MANAGEMENT : Sustainable Competitive Advantage, 7(September), 303-324.

Waluyo, W. (2017). Firm Size , Firm Age , and Firm Growth on Corporate Social Responsibility in Indonesia: The Case of Real Estate Companies. European Research Study Journal, XX(4), 360369.

Wuryani, E. (2012). COMPANY SIZE IN RESPONSE TO EARNINGS MANAGEMENT. Journal of Economics, Business, and Accountancy Ventura, 15(3), 491-506.

Zimmerman, J. L. (1983). TAXES AND FIRM SIZE. Journal of Accounting and Economics, 5(June), 119-149. 